\title{
NITROGEN-DEFICIENT MICROALGAE ARE RICH IN CELL-SURFACE MANNOSE: POTENTIAL IMPLICATIONS FOR PREY BIORECOGNITION BY PHAGOTROPHIC PROTOZOA
}

\author{
Claire M. Martel
}

Institute of Life Science, School of Medicine, Swansea University, Singleton Park, SA2 8PP, UK

Submitted: January 09, 2008; Returned to authors for corrections: April 06, 2008; Approved: February 17, 2009.

\section{SHORT COMMUNICATION}

\begin{abstract}
Flow cytometry was used to quantify the abundance of mannose-linked glycoconjugates on microalgae precultured using low- or high-nitrate media. Nitrogen-deficient microalgae were richer in cell-surface mannose than nitrogen-sufficient. Findings are discussed in view of recent research which reveals mannose-specific 'feeding receptors' assist prey biorecognition by phagotrophic protozoa that ingest microalgae.
\end{abstract}

Key-words: microalgae, biorecognition, phagotrophic protozoa, mannose

Phagotrophic protozoa exert top-down control in pelagic ecosystems, consuming microalgae (3), bacteria (24), and other protozoa. Through grazing activities marine protozoa impact the structure and succession of microbial communities (13), and nutrient fluxes in the ocean (22). Over an evolutionary timescale, protistan predation pressure is suspected to have driven the development of anti-grazing mechanisms in species of bacteria (9). Given their ecological significance, it is not surprising that, since the formal recognition of marine 'microbial loop' communities $(2,18)$, the feeding habits of phagotrophic protozoa continue to attract attention. Today the focus of much marine protistan research centres on observations which suggest that, far from being indiscriminate grazers, many protozoans display high levels of selectivity when feeding. The rejection of 'poor-quality' prey (e.g. nutrient-deficient microalgae) by predatory cells is a recurrent theme in marine literature $(7,10,16,21)$. The ingestion traits of phagotrophic protozoa warrant investigation because some predatory species have been considered as biological control agents for nuisance, bloom-forming microalgae (11). The toxicity of many such algae is exacerbated under nutrient-imbalanced conditions $(12,25)$.

Some 16 years ago it was proposed that certain protozoa might use 'contact chemoreceptors' to discern the profitability of different prey items on the basis of their cell-surface biochemical composition (28). However, exploration of molecular-level signalling and recognition processes between predatory and prey cells has only been pursued more recently $(23,26,27,32)$. Of significance are the recent findings of Wootton et al. (32) who identify a mannose-specific feeding receptor on the phagotrophic protozoan Oxyrrhis marina - a marine species in which selective feeding is well-documented $(7,10,16,29)$. Wootton and colleagues demonstrate that ingestion of the microalga Isochrysis galbana by $O$. marina can be inhibited by saturating receptor binding domains with mannose-BSA (32). They postulate that $O$. marina might utilise feeding receptors to recognise mannose moieties on potential prey items (e.g. microalgae $[5,19]$ ) and highlight functional similarities between protistan feeding receptors and macrophage mannose receptors which recognise highly conserved carbohydrate motifs on pathogenic organisms (4). Interestingly, the obligate and highly specific relationship between symbiotic dinoflagellates and reef building corals is already understood to be mediated by lectinglycan interactions (31). Furthermore, a mannose-rich cell wall glycoprotein on the red microalga Porphyridium sp. is suspected to act as a biorecognition site for its specialist predator, a Crypthecodinuim cohnii-like protozoan $(23,26,27)$. The possibility that lectin-carbohydrate interactions might also

*Corresponding Author. Mailing address: Institute of Life Science, School of Medicine, Swansea University, Singleton Park, SA2 8PP, UK. Tel./Fax: +44 1792205678 extension: 5417. E-mail: c.m.martel@swansea.ac.uk 
be implicated in prey biorecognition and/or selection is clearly feasible, but now requires further investigation.

In experiments reported here, a flow cytometric protocol optimised for marine microalgae (19), was used to quantify the density of cell-surface mannose on Isochrysis galbana that had been precultured using low- or high-nitrate $f / 2$ nutrient media (8). Pertinently, O. marina (the phagotrophic protozoan on which mannose-specific feeding receptors have been revealed) has been observed to select against $I$. galbana in mixed prey feeding experiments $(7,10,16)$; the 'distaste' shown towards I. galbana is interesting, because it is typically associated with elevated C:N ratios in I. galbana. The aim of this study was simply to determine whether-or-not nitrogen stress affects the abundance of mannose residues displayed at the cell-surface of I. galbana. Given that mannose-specific feeding receptors are implicated in the process of prey recognition by phagotrophic protozoa (32), it was hypothesised that nitrogen-sufficient (good-quality) I. galbana might produce more cell-surface mannose than nitrogen-limited (poor-quality) I. galbana. As a consequence good-quality $I$. galbana might be more readily adhered to and ingested.

Axenic, Isochrysis galbana Parke (CCAP 927/1) were cultured using modified $f / 2$ seawater-based media with $110 \mu \mathrm{M}, 220 \mu \mathrm{M}$, $440 \mu \mathrm{M}$ or $880 \mu \mathrm{M}$ nitrate. Cultures were maintained at $18^{\circ} \mathrm{C}$ under an 18:6h light:dark cycle $\left(180 \mu \mathrm{mol}\right.$ photons $\left.\mathrm{m}^{1} \mathrm{~s}^{1}\right)$. The cell numbers and biovolume (biomass concentrations [7]) of $I$. galbana populations were monitored using an Elzone 282 PC Particle analyser (Particle data Inc). Stationary phase I. galbana cultures were used for experimental work; these were established by constant consecutive cell counts and biovolume values. Cellular nitrogen:carbon $(\mathrm{N}: \mathrm{C})$ ratios (Table 1) were estimated from stationary phase biovolume assuming $1 \mathrm{~L}=200 \mathrm{gC} \mathrm{(30)}$ and initial nitrate concentrations assuming that all was converted to cell-N. I. galbana populations cultured using i) $110 \mu \mathrm{M}$ and $2200 \mu \mathrm{M}$, ii) $440 \mu \mathrm{M}$ or iii) $880 \mu \mathrm{M}$ nitrate were considered to be nitrogen-limited, nitrogen-stressed or nitrogen sufficient, with $\mathrm{N}: \mathrm{C}$ values of $0.04 \mathrm{gN} \cdot(\mathrm{gC})^{-1}, 0.06 \mathrm{gN} \cdot(\mathrm{gC})^{-1}$ or $0.10 \mathrm{gN} \cdot(\mathrm{gC})^{-1}$ respectively (Table 1).

Fluorescein isothiocyanate-labelled Con A (FITC-Con A) isolated from the jack bean, Canavalia ensiformis (Vector laboratories) was used to label cell surface mannose residues on all stationary phase I. galbana populations according to the methodology of Roberts et al. (19). Briefly, $1 \mathrm{~mL}$ volumes from each I.galbana population $\left(\approx 1.0 \times 10^{6}\right.$ cells $\left.\mathrm{mL}^{-1}\right)$ were centrifuged (30sec, 600 $\mathrm{g}$ ) and resuspended in filtered seawater (FSW). Cells were then incubated with $1 \%(\mathrm{v} / \mathrm{v})$ bovine serum albumin (BSA) for $30 \mathrm{~min}$. BSA was removed using micro-centrifugation ( and $\times 3$ washing steps with FSW) and cells were incubated for $30 \mathrm{~min}$ in the dark with FITC-Con A $\left(50 \mu \mathrm{g}\right.$ lectin protein $\left.\mathrm{mL}^{-1}\right)$. Following the labelling period, micro-centrifugation was used to remove unbound FITC-Con A from the supernatant, and I. galbana were fixed with $2 \%(\mathrm{v} / \mathrm{v})$ ice-cold formaldehyde. Negative control populations were prepared (as described) following preincubation
Table 1. Carbon and nitrogen biomass of Isochrysis galbana populations precultured using $110 \mu \mathrm{M}, 220 \mu \mathrm{M}, 440 \mu \mathrm{M}$ and $880 \mu \mathrm{M}$ nitrate.

\begin{tabular}{|c|c|c|c|c|c|c|}
\hline $\begin{array}{l}\text { Precu } \\
(\mu \mathrm{M})\end{array}$ & $\begin{array}{l}\text { lture } \mathrm{N} \\
(\mu \mathrm{g} \mathrm{N} \\
\left.\mathrm{mL}^{-1}\right)\end{array}$ & $\begin{array}{c}\text { Density } \\
\text { (Cells } \\
\left.\mathrm{mL}^{-1}\right)\end{array}$ & $\begin{array}{c}\text { Biovolume } \\
(\mathrm{nL} \\
\mathrm{mL})\end{array}$ & $\begin{array}{c}\text { Biomass } \\
(\mu \mathrm{g} \mathrm{C} \\
\left.\mathrm{mL}^{-1}\right)\end{array}$ & $\begin{array}{c}\mathrm{C}: \mathrm{N} \\
(\mathrm{gC} \cdot \\
{\left[\mathrm{gN}^{-1}\right)}\end{array}$ & $\begin{array}{c}\mathrm{N}: \mathrm{C} \\
(\mathrm{gN} \cdot \\
\left.[\mathrm{gC}]^{-1}\right)\end{array}$ \\
\hline 110 & 1.54 & $3.5 \times 10^{6}$ & 207 & 41.3 & 26.8 & 0.04 \\
\hline 220 & 3.58 & $5.5 \times 10^{6}$ & 347 & 69.3 & 22.5 & 0.04 \\
\hline 440 & 6.16 & $8.0 \times 10^{6}$ & 520 & 104 & 16.9 & 0.06 \\
\hline 880 & 12.32 & $10.1 \times 10^{6}$ & 645 & 138 & 10.5 & 0.10 \\
\hline
\end{tabular}

of FITC-Con A with $50 \mathrm{mM} \mathrm{D}$-mannose for $1 \mathrm{hr}$. These treatments accounted for any non-specific binding of FITC-Con A to $I$. galbana. The chlorophyll and FITC fluorescence properties of i) FITC-Con A treated, ii) negative control, and iii) untreated I.galbana precultured using $110 \mu \mathrm{M}, 220 \mu \mathrm{M}, 440 \mu \mathrm{M}$ and 880 $\mu \mathrm{M}$ nitrate were quantified using flow cytometry (FACSAria, BD Biosciences). All cell preparations were excited using a $488 \mathrm{~nm}$ argon laser and I. galbana were identified in dot plot comparisons (BD FACSDiVa software) of forward scatter (FSC A) and chlorophyll fluorescence (PerCP). The intensity of chlorophyll fluorescence signals $(675 \pm 20 \mathrm{~nm})$, and FITC fluorescence signals in the range of fluorescein isothiocyanate $(530 \pm 30 \mathrm{~nm})$ from 2.0 $\times 10^{4}$ untreated I. galbana were recorded from histogram outputs. These were compared with chlorophyll and FITC fluorescence signals from negative control and FITC-Con A treated I. galbana (Fig. 1). The intensity of FITC fluorescence that resulted from the binding of FITC-Con A to I. galbana was determined by subtracting FITC fluorescence from negative control populations from the total FITC fluorescence of FITC-Con A treated I. galbana. Spearman's rank $\left(r_{\mathrm{s}}\right)$ correlation coefficients for comparison of the nitrogen status of all I. galbana populations with their fluorescence properties were computed using SPSS (Version 13.0).

The intensity of chlorophyll fluorescence was clearly coupled with the nitrogen status of I. galbana (Fig. 1a). Chlorophyll fluorescence signals from nitrogen-limited $I$. galbana (cultured using $110 \mu \mathrm{M}$ and $220 \mu \mathrm{M}$ nitrate) were always lower than those from nitrogen-stressed ( $440 \mu \mathrm{M}$ nitrate) and nitrogen-sufficient $(880 \mu \mathrm{M}$ nitrate) I. galbana. FITC fluorescence signals were positively, and significantly $(P<0.01)$ correlated with increases in the nitrogen status of untreated, and negative control I. galbana $\left(r_{\mathrm{s}}=0.734\right.$, and $r_{\mathrm{s}}=0.842$ respectively). In contrast, a strong, negative correlation was found between I. galbana nitrogen status and FITC fluorescence resulting from the binding of FITC-Con A $\left(r_{\mathrm{s}}=\right.$ $-0.885, P<0.01, \mathrm{n}=12)$. A strong, negative correlation was also found between the intensity of chlorophyll and FITC fluorescence signals (resulting from binding of FITC-Con A) in FITC-Con A treated I. galbana $\left(r_{\mathrm{s}}=-0.874, P<0.01, \mathrm{n}=12\right)$. 


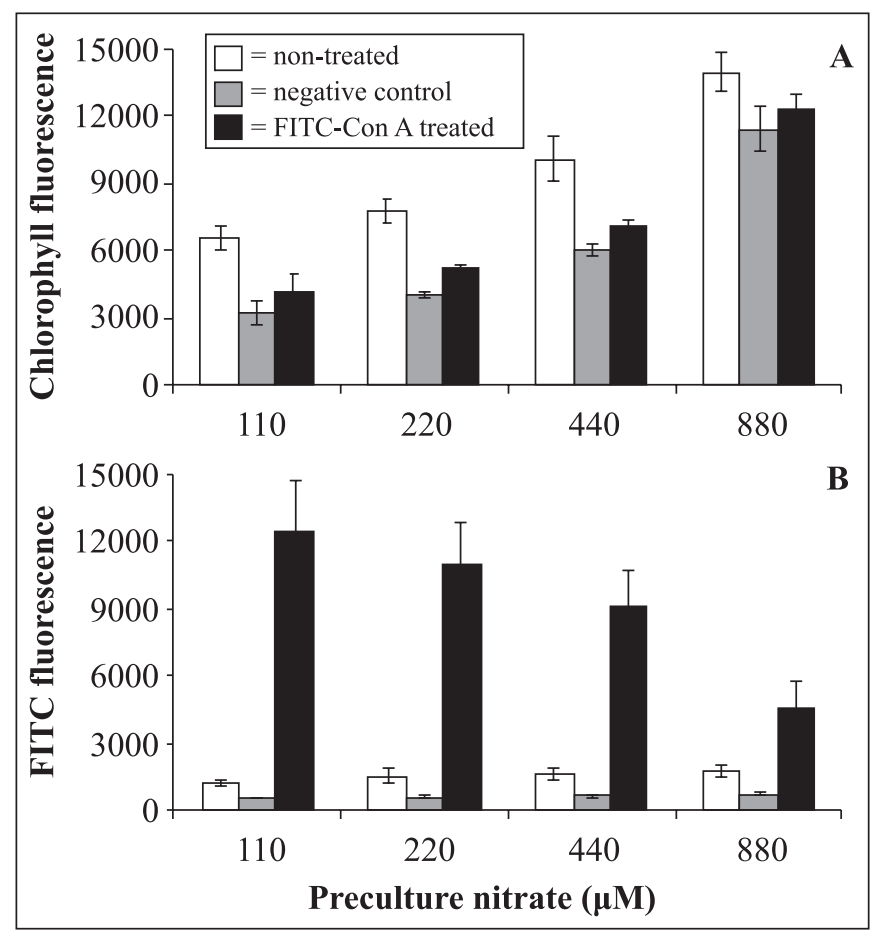

Figure 1. Fluorescence properties of Isochrysis galbana precultured using $110 \mu \mathrm{M}, 220 \mu \mathrm{M}, 440 \mu \mathrm{M}$ and $880 \mu \mathrm{M}$ nitrate. Mean ( \pm SD) chlorophyll fluorescence (A) and FITC fluorescence (B) signals. Chlorophyll fluorescence $=675 \pm 20 \mathrm{~nm}$; FITC fluorescence $=$ signals in the range of fluorescein isothiocyanate $(530 \pm 30 \mathrm{~nm})$.

It is interesting that nitrogen-limited I. galbana were richer in cell-surface mannose than nitrogen-stressed and nitrogensufficient I. galbana. This finding supports those of Köst et al. (14) and Arad et al. (1) who that found that nitrogen stress enhances cell wall polysaccharide production in other species of marine microalgae. It is possible that under nitrogen-limited growth conditions, nitrogenous chlorophylls are degraded in microalgae (6) and that carbohydrate (including mannose) residues are metabolised to sequester excess carbon. However, while the physiological responses to nitrogen-stress might be relatively straightforward, the implications of these responses on prey biorecognition by phagotrophic protozoa are less clear.

If the mannose-specific protozoan feeding receptor identified by Wootton et al. (32) enables predatory cells to adhere to potential prey items, then it might be reasoned that poor-quality (mannose-rich) microalgae would be captured and ingested more readily. However, previous studies suggest that this is not the case $(7,10,16,21)$. Alternatively, it may be that mannose-rich, poorquality microalgae are actually too sticky for protozoan predators to adhere to. Excess cell-surface mannose residues on nitrogendeficient microalgae, may shear off and inhibit the binding efficiency of feeding receptors (as demonstrated by sugar inhibition experiments conducted by Wootton et al. [32]). Furthermore, it is possible that the enhanced production of preysurface glycoconjugates under conditions of nitrogen stress could accentuate the influence of repulsive (negative-negative) electrostatic forces between predatory and prey cells (see Ryter $\&$ deChastellier [20]). Given that cell-cell interactions in higher organisms are mediated by crosstalk between different classes of receptors (4), it is possible that numerous mechanisms are involved in the process of prey recognition by phagotrophic protozoa. Protozoan feeding receptors may recognise subtle differences in the arrangement and branching of carbohydrate residues on poor-quality and good-quality prey items (4). Alternatively, predatory cells may possess receptors which recognise specific 'eat me' or 'don't eat me' signals on potential prey items. Such cues could be of carbohydrate origin or of a completely different chemical nature.

This report has focused on the potential for phagotrophic protozoa to recognise differences between the carbohydrate biochemistry of poor- and good-quality microalgae. However, the possibility that the 'distaste' shown towards certain microalgae is simply an artefact resulting from the action of inhibitory prey-associated compounds should not be overlooked. Evidence for grazing-activated chemical defence in marine microalgae underscores this consideration (29). Interestingly, the release of toxic superoxide $\left(\mathrm{O}^{2}\right.$. $)$ anions from the marine microalgae Chattonella marina and Heterosigma akashiwo is exacerbated following stimulation with the mannose-specific lectin Con A(17). Given the results of this present study and recent evidence for superoxide production by numerous marine microalgae (including I. galbana [15]), it is possible that lectin-stimulated superoxide production could constitute a novel model for grazing-activated chemical defence. It follows that when mannose-specific predator feeding receptors (32) interact with mannose-linked prey-surface glycoconjugates (this study), superoxide may be released in an oxidative burst which deters protozoan predators. Enhanced levels of $\mathrm{O}^{2}$. production may be associated with 'poor-quality' prey (e.g. nitrogen-limited I. galbana) because they are richer in the cell-surface mannose glycoconjugates that protozoan feeding receptors bind to. In this way, the feeding preferences of predatory cells might be inextricably associated with receptormediated modes of prey biorecognition. Exploration of the possibility that planktonic protozoa may be able to 'taste' potential prey items prior to the ingestion phase is an exciting avenue for protistan research. Further investigation of a greater range of potential receptor-ligand recognition complexes (and interactions between them) is now required.

\section{ACKNOWLEDGEMENTS}

Financial support: Natural Environmental Research Council (NERC, UK). 


\section{RESUMO}

\section{Microalgas com deficiência de nitrogênio são enriquecidas com manose na superfície celular: potenciais implicações para reconhecimento de presas por protozoários fagotróficos}

Citometria de fluxo foi usada para quantificar a abundância de glicoconjugados com manose em precultivos de microalgas usando meios com baixo e alto teor de nitrato. Microalgas com deficiências de nitrogênio tinham mais manose na superfície celular do que as com nitrogênio suficiente. Resultados são discutidos com base nas pesquisas recentes que revelam receptores específicos para manose que auxiliam no reconhecimento da presa por protozoários fagotróficos que ingerem microalgas.

Palavras-chave: microalgas, reconhecimento de presas, protozoários fagotroficos, manose.

\section{REFERENCES}

1. Arad, S.M.; Lerental, Y.B.; Dubinsky, O. (1992). Effect of nitrate and sulfate starvation on polysaccharide formation in Rhodella reticulata. Bioresour. Technol., 42, 141-148.

2. Azam, F.; Fenchel, T.; Field, J.G.; Gray, J.S.; Meyerreil, L.A.; Thingstad, F. (1983). The ecological role of water-column microbes in the sea. Mar. Ecol. Prog. Ser., 10, 257-263.

3. Calbet, A.; Landry, M.R. (2004). Phytoplankton growth, microzooplankton grazing, and carbon cycling in marine systems. Limnol. Oceanog., 49, 51-57.

4. Cambi, A.; Koopman, M.; Figdor, C.G. (2005). How C-type lectins detect pathogens. Cell. Microbiol., 7, 481-488.

5. Cho, E.S. (2003). Cluster analysis on the lectin binding patterns of marine microalgae. J. Plankton. Res., 25, 309-315.

6. Davidson, K.; Flynn, K.J.; Cunningham, A. (1991). Relationships between photopigments, cell carbon, cell nitrogen and growth-rate for a marine nanoflagellate. J. Exp. Mar. Biol. Ecol., 153, 87-96.

7. Flynn, K.J.; Davidson, K.; Cunningham, A. (1996). Prey selection and rejection by a microflagellate; implications for the study and operation of microbial food webs. J. Exp. Mar. Biol. Ecol., 196, 357-372.

8. Guillard, R.R.L. (1975). Culture of phytoplankton for feeding marine invertebrates. In: Smith, W.L., Chanley, M.H. (eds). Culture of marine invertebrates. Plenum Press: New York, p. 26-60.

9. Hahn, M.W.; Lunsdorf, H.; Janke, L. (2004). Exopolymer production and microcolony formation by planktonic freshwater bacteria: defence against protistan grazing. Aquat. Microb. Ecol., 35, $297-$ 308.

10. Hansen, F.C.; Witte, H.J.; Passarge, J. (1996). Grazing in the heterotrophic dinoflagellate Oxyrrhis marina: Size selectivity and preference for calcified Emiliania huxleyi cells. Aquat. Microb. Ecol., 10, 307-313.

11. Jeong, H.J.; Kim, J.S.; Yeong, D.Y.; Kim, S.T.; Kim, T.H.; Park, M.G. et al. (2003). Feeding by the heterotrophic dinoflagellate Oxyrrhis marina on the red-tide raphidophyte Heterosigma akashiwo: a potential biological method to control red tides using mass-cultured grazers. J. Eukaryot. Microbiol., 50, 274-282.

12. John, E.H.; Flynn, K.J. (2000). Growth dynamics and toxicity of Alexandrium fundyense (Dinophyceae): the effect of changing N:P supply ratios on internal toxin and nutrient levels. Eur. J. Phycol., $35,11-23$

13. Jürgens, K.; Matz, C. (2002). Predation as a shaping force for the phenotypic and genotypic composition of planktonic bacteria. Anton. Leeuwenhoek. Int. J. Gen. M., 81, 413-434.

14. Köst, H.P.; Senser, M.; Wanner, G. (1984). Effect of nitrate and sulfate starvation on Porphyridium cruentum cells. Z. Pflanzenphysiol. $113,231-249$

15. Marshall, J.A.; Ross, T.; Pyecroft, S.; Hallegraeff, G. (2005) Superoxide production by marine microalgae. Mar. Biol., 147, 541549.

16. Martel, C.M. (2006). Prey location, recognition and ingestion by the phagotrophic marine dinoflagellate Oxyrrhis marina. J. Exp. Mar. Biol. Ecol., 335, 210-220.

17. Oda, T.; Nakamura, A.; Okamoto, T.; Ishimatsu, A.; Muramatsu, T. (1998). Lectin-induced enhancement of superoxide anion production by red tide phytoplankton. Mar. Biol., 131, 383-390.

18. Pomeroy, L.R. (1974). The oceans food web, a changing paradigm. Bioscience., 24: 499-504.

19. Roberts, E.C.; Zubkov, M.V.; Martin-Cereceda, M.; Novarino, G.; Wootton, E.C. (2006). Cell surface lectin-binding glycoconjugates on marine planktonic protists. FEMS. Microbiol. Lett., 265, 202207.

20. Ryter, A.; deChastellier, C. (1983). Phagocyte-pathogenic microbe interactions. Int. Rev. Cytol., 5, 287-327.

21. Shannon, S.P.; Chrzanowski, T.H.; Grover, J.P. (2007). Prey food quality affects flagellate ingestion rates. Microb. Ecol., 53: 66-73.

22. Sherr, E.B.; Sherr, B.F. (2002). Significance of predation by protists in aquatic microbial food webs. Anton. Leeuwenhoek. Int. J. Gen. M., 81, 293-308.

23. Shrestha, R.P.; Weinstein, Y.; Bar-Zvi, D.; Arad, S. (2004). A glycoprotein noncovalently associated with cell-wall polysaccharide of the red microalga Porphyridium sp (Rhodophyta). J. Phycol., 40, 568-580.

24. Simek, K.; Chrzanowski, T.H. (1992). Direct and indirect evidence of size-selecctive grazing on pelagic bacteria by fresh-water nanoflagellates. Appl. Environ. Microbiol., 58, 3715-3720.

25. Stolte, W.; Lindstrom, T.; Graneli, E. (2007). Enhancement of poorly edible phytoplankton by allochthonous dissolved organic material a modelling study. Aquat. Microb. Ecol., 46, 263-272.

26. Ucko, M.; Geresh, S.; Simonberkovitch, B.; Arad, S.M. (1994). Predation by a dinoflagellate on a red microalga with a cell wall modified by sulfate and nitrate starvation. Mar. Ecol. Prog. Ser. 104, 293-298.

27. Ucko, M.; Shrestha, R.P.; Mesika, P.; Bar-Zvi, D.; Arad, S. (1999). Glycoprotein moiety in the cell wall of the red microalga Porphyridium sp (Rhodophyta) as the biorecognition site for the Crypthecodinium cohnii-like dinoflagellate. J. Phycol., 35, 1276 1281.

28. Verity, P.G. (1991). Feeding in planktonic protozoans - evidence for non-random acquisition of prey. J. Protozool., 38, 69-76.

29. Wolfe, G.V.; Steinke, M.; Kirst, G.O. (1997). Grazing-activated chemical defence in a unicellular marine alga. Nature., 387, 894897.

30. Wood, G.J.; Flynn, K.J. (1995). Growth of Heterosigma carterae (Raphidophyceae) on nitrate and ammonium at three photon flux densities: Evidence for $\mathrm{N}$ stress in nitrate-growing cells. J. Phycol., 31, 859-867.

31. Wood-Charlson, E.M.; Hollingsworth, L.L.; Krupp, D.A.; Weis, V.M (2006). Lectin/glycan interactions play a role in recognition in a coral/dinoflagellate symbiosis. Cell. Microbiol., 8, 1985-1993.

32. Wootton, E.C.; Zubkov, M.V.; Jones, D.H.; Jones, R.H.; Martel, C.M.; Thornton, C.A.; Roberts, E.C. (2007). Biochemical prey recognition by planktonic protozoa. Environ. Microbiol., 9, 216222 . 